\title{
PENDIDIKAN ANAK USIA DINI DALAM AL-QUR'AN
}

\author{
Nurfitriana \\ Program Pascasarjana PGMI UIN Sultan Syarif Kasim Riau \\ Email: nurfitrianayudha@gmail.com /085375647832
}

\begin{abstract}
This research is a library research. Data collection is done by collecting primary and secondary data sources. In analyzing the data that has been collected the authors use data analysis (content analysis), namely the interpretation method used in explaining the contents of the Qur'anic verses from various aspects by observing the verses of the Qur'an 'as stated in the manuscript. Start by mentioning verses that must be interpreted, explaining the meaning of lafadz contained in them. Then the verses that are interpreted are described and analyzed clearly, so the conclusions can be drawn. The Qur'an as the holy book of Muslims serves as a guide for pious people, the instructions here are general meanings, which means that the Koran besides being the right road guide and blessed by Allah and will give happiness in the hereafter also means as a guide in climbing life in the world. Because the point is that Islam always teaches its people to always achieve happiness in living in the world and the hereafter. The child is the hope of the future and the successor to continuity and survival. Because of that the task of parents is to educate and direct their children according to the talents they have. Because in childhood this was full of great curiosity, they wanted to be individuals who had adequate abilities according to their level of maturity. If from an early age, the child gets a good chance, then later he will be a creative person and get provisions for his future.
\end{abstract}

Keywords: Education, Children, Qur'an, Islam

\begin{abstract}
Abstrak
Penelitian ini merupakan penelitian kepustakaan. Pengumpulan data dilakukan dengan mengumpulkan sumber data primer dan sekunder. Dalam menganalisa data yang telah dikumpulkan penulis menggunakan analisis data (content analysis) yaitu metode interpretasi yang digunakan dalam menjelaskan isi ayat-ayat Alquran dari berbagai aspek dengan memperhatikan ayat-ayat Al Qur'an ' sebuah sebagaimana tercantum dalam manuskrip. Mulailah dengan menyebutkan ayat-ayat yang harus ditafsirkan, menjelaskan arti lafadz yang terkandung di dalamnya. Kemudian ayat-ayat yang ditafsirkan dideskripsikan dan dianalisis dengan jelas, sehingga kesimpulan bisa ditarik. Alquran sebagai kitab suci umat Islam berfungsi sebagai panduan bagi orang yang saleh, petunjuk di sini adalah makna umum, yang berarti Alquran selain menjadi panduan jalan yang benar dan diberkati oleh Allah dan akan memberikan kebahagiaan dalam akhirat juga berarti sebagai panduan dalam memanjat kehidupan di dunia. Karena intinya Islam selalu mengajarkan umatnya untuk selalu mencapai kebahagiaan hidup di dunia dan akhirat. Anak adalah harapan masa depan dan penerus kelangsungan dan
\end{abstract}


kelangsungan hidup. Karena itu tugas orang tua adalah mendidik dan mengarahkan anak mereka sesuai dengan talenta yang mereka miliki. Karena pada masa kanak-kanak ini penuh dengan keingintahuan yang besar, mereka berkeinginan untuk menjadi individu yang memiliki kemampuan memadai sesuai dengan tingkat kedewasaannya. Jika sejak usia dini, anak mendapat kesempatan bagus, maka nanti dia akan menjadi orang kreatif dan mendapatkan bekal untuk masa depannya.

Kata kunci: Pendidikan, Anak, Qur'an, Islam

\section{A. Pendahuluan}

Pendidikan adalah hak warga negara, tidak terkecuali pendidikan pada anak usia dini yang juga merupakan hak warga negara dalam mengembangkan potensinya sejak dini. Berdasarkan berbagai penelitian bahwa usia ini merupakan pondasi terbaik dalam mengembangkan kehidupannya di masa depan. Selain itu pendidikan di usia dini dapat mengoptimalkan kemampuan dasar anak dalam menerima proses pendidikan di usia-usia berikutnya. Pendidikan merupakan salah satu aspek dalam kehidupan yang harus dijalani oleh seluruh umat manusia, karena dalam agamapun kita diwajibkan untuk menuntut ilmu sampai akhir hayat.

Pendidikan mendapat perhatian yang sangat serius dalam agama Islam. Hal ini bisa dicermati dari wahyu yang pertama kali turun di mana diserukan perintah untuk "membaca" (iqra'). ${ }^{1}$ Perintah "membaca" pada dasarnya merupakan anjuran yang sangat kuat mengenai pentingnya pendidikan dalam Islam.

Mengingat betapa pentingnya posisi anak dalam keluarga, maka Islam pun menyerukan agar mengelola potensi anak dengan sungguh-sungguh. Seruan ini untuk menghindarkan agar jangan sampai anak ditelantarkan sehingga menjadi tumbuh menjadi manusia yang lemah dalam segala hal. Seruan secara eksplisit diungkap dalam Surat anNisa' [4]: 9:

"Dan hendaklah takut kepada Allah orang-orang yang seandainya meninggalkan di belakang mereka anak-anak yang lemah, yang mereka khawatir terhadap (kesejahteraan) mereka. Oleh sebab itu hendaklah mereka bertakwa kepada Allah dan hendaklah mereka mengucapkan perkataan yang benar."

Anak yang dilahirkan dari orangtua yang baik maka ia berpotensi untuk menumbuhkan sifat-sifat baik dalam dirinya. Namun apabila anak tersebut hidup dalam lingkungan yang rusak, dan berakhlak rendah maka anak tersebut bisa menjadi orang yang suka merusak dan jahat. Sebaliknya anak yang dilahirkan dari orang tua yang jahat berpotensi menumbuhkan sifat-sifat tercela dalam perilakunya. Seandainya hidup dalam lingkungan yang penuh dengan kebaikan dan diserahkan kepada pendidik yang baik, ada

\footnotetext{
${ }^{1}$ Nur Faizah, Sejarah Al-Qur'an, Jakarta: Artharivera, 2008, hal. 64.

${ }^{2}$ Al-Qur'an surat An- Nisa ayat 9
} 
kemungkinan sifat-sifat buruk mereka akan tertutupi dan tumbuh menjadi orang yang memiliki keutamaan dan keimanan.

Seorang anak pada usia dini mempunyai daya tangkap yang kuat dalam menerima pendidikan. Dia memiliki kecenderungan untuk ingin tahu atau mengamati segala sesuatu yang ada disekelilingnya. Pada masa itu, dia memiliki kebebasan yang cukup besar dan tidak atau belum menerima ajaran atau berbagai pengalaman pahit lainnya. Oleh karena itu, setiap anak senantiasa akan mendengar, melihat menikmati atau merasakan berbagai hal yang cukup dan hal-hal yang baru selama ia mampu mempersiapkan dirinya untuk melaksakan semua itu. Mayoritas anak-anak apabila mendapat stimulant maka mereka akan menciptakan maupun menikmati keindahan, mencintai, seseorang dan mempercayai seluruh pengetahuan tersebut dengan senang hati. Semua itu merupakan kesempatan yang baik untuk membiasakan mereka berpikir ilmiah dan cermat.

Anak-anak adalah harapan masa depan dan penerus kelangsungan serta kelanjutan hidup. Oleh karena itu tugas orang tua adalah mendidik dan mengarahkan anak-anaknya sesuai dengan talenta yang dimiliki. Karena pada anak usia dini penuh dengan rasa ingin tahu yang besar, mereka berhasrat untuk menjadi seorang individu yang memiliki kemampuan memadai sesuai dengan taraf kedewasaannya. Bila sejak usia dini, seorang anak memperoleh kesempatan baik, maka kemudian hari ia akan menjadi orang yang kreatif.

Masarudin Siregar menyebutkan bahwa, setiap negara mempunyai sistem pendidikan, karena sistem pendidikan merupakan perwujudan dan penjabaran dari cita-cita masyarakat. Harapan masyarakat terhadap pendidikan adalah sangat besar karena pendidikan diharapkan dapat mewujudkan cita-cita masyarakat. Pendidikan berfungsi sebagai the agent of social change. Dari sana Nampak dengan jelas bahwa peran pendidikan merupakan tumpuan harapan masyarakat untuk menghasilkan sumber daya manusia yang berkualitas tinggi sehingga siap dan mampu untuk memasuki kurun waktu yang mengandung tantangan baru, inspirasi baru, dan kekuatan baru yang muncul dalam masyarakat yang bergerak dinamis. ${ }^{3}$

\section{B. Pembahasan}

\section{Pengertian Pendidikan Anak}

Istilah pendidikan berasal dari kata "didik" yang diberi awalan "pe" dan akhiran "kan", mengandung arti "perbuatan" (hal, cara dan sebagainya). Isitilah pendidikan ini semula berasal dari bahasa yunani yaitu "Paedagogie", yang berarti bimbingan yang diberikan kepada anak. ${ }^{4}$ Dalam Kamus Besar Bahasa Indonesia pendidikan ialah "Proses perubahan sikap dan tata laku seseorang atau kelompok orang dalam usaha mendewasakan manusia melalui upaya pengajaran dan pelatihan. ${ }^{5}$

\footnotetext{
${ }^{3}$ Masarudin Siregar, Filsafat Pendidikan Islam, (Semarang: Fakultas Tarbiyah, 2003), h. 16

${ }^{4}$ Ramayulis, Ilmu Pendidikan Islam, Jakarta: Kalam Mulia, 2002, h.13.

${ }^{5}$ Tim Penyusun Kamus Pusat Pembinaan dan Pengembangan Bahasa Departemen Pendidikan dan Kebudayaan, Kamus Besar Bahasa Indonesia, Jakarta: Balai Pustaka, 1994, Edisi Kedua, h.232
} 
Definisi pendidikan dalam Undang-Undang Dasar Republik Indonesia Nomor 20 Tahun 2003 tentang sistem Pendidikan Nasional bab I ayat I dikemukakan: "Pendidikan adalah usaha sadar dan terencana untuk mewujudkan suasana belajar dan proses pembelajaran agar peserta didik secara aktif mengembangkan potensi dirinya untuk memiliki kekuatan spiritual keagamaan, pengendalian diri, kepribadian, kecerdasan, akhlak mulia serta keterampilan yang diperlukan dirinya, masyarakat, bangsa dan Negara. ${ }^{6}$

Pendidikan merupakan upaya sadar untuk menumbuh kembangkan potensi sumber daya manusia peserta didik dengan cara mendorong dan memfasilitas kegiatan belajar mereka. ${ }^{7}$ Sedangkan arti pendidikan dalam islam kita kenal dengan istilah tarbiyah, ta'lim dan ta'dib. Kata tarbiyah menurut Abdurrahman al-Nahlawi berasal dari tiga kata yaitu: raba-yarbu yang berarti bertambah, bertumbuh.

Kedua, rabiya-Yarba yang berarti besar, dan yang ketiga rabba-yurabbu yang berarti memperbaiki, menguasai urusan, menuntun, menjaga dan memelihara. ${ }^{8}$ Sedangkan kata ta' lim berasal dari kata 'allama-yu'allimu-Ta'liman yang berarti mengajarkan suatu ilmu kepada seseorang agar memiliki pengetahuan tentang sesuatu. Seseorang mengajarkan tentang ilmu pengetahuan kepada orang lain agar orang tersebut memiliki ilmu pengetahuan. Konteks ta'lim ini lebih mengacu kepada aspek kognitif.'

Istilah ta'dib menurut al-Attas merupakan istilah yang paling tepat dalam menunjukan pendidikan Islam, al-Attas mengacu kepada hadist Nabi saw. Ta'dib diartikan olehnya sebagai pengenalan dan pengakuan secara berangsur-angsur yang ditanamkan ke diri manusia atau peserta didik tentang tempat-tempat yang tepat dari segala sesuatu di dalam tatanan penciptaan. Dengan pendekatan ini, pendidikan akan berfungsi sebagai pembimbing ke arah pengenalan dan pengakuan tempat Tuhan yang lebih tepat dalam tatanan wujud dan kepribadian. ${ }^{10}$

Menurut Hasan Langgulung istilah education dalam bahasa inggris yang berasal dari bahasa latin educere berarti memasukkan sesuatu. Istilah pendidikan mengacu pada terminologi tarbiyah, ta'lim, ta'dib. Istilah tarbiyah berasal dari kata rabba-yurabbi yang menunjukkan arti berkembang. ${ }^{11}$ Penggunaan kata tarbiyah yang menunjukkan makna pendidikan dapat dipahami dalam firman Allah SWT dalam surat Al-isra' ayat 24 yang berbunyi:

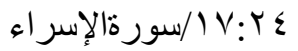

Dan rendahkanlah dirimu terhadap mereka berdua dengan penuh kesayangan dan ucapkanlah: "Wahai Tuhanku, kasihilah mereka keduanya, sebagaimana mereka berdua telah mendidik aku waktu kecil". (Q.S. al-Israa/17:24) ${ }^{12}$

\footnotetext{
${ }^{6}$ Lif Khoiro Ahmadi, Hendro, Sofan, Pembelajaran Akselerasi, Jakarta: PT Prestasi Pustaka, 1998, Cet. Ke.1 h.204.

${ }^{7}$ Muhibin Syah, Psikologi Belajar, Jakarta: PT. Raja Grafindo Persada, 2003, h.13

${ }^{8}$ Ahmad Tafsir, Ilmu Pendidikan Islam, Bandung: Remaja Rosda Karya, 2007, Cet. VII, h.29.

${ }^{9}$ A. Fattah Yasin, Dimensi-dimensi Pendidikan Islam, Malang: UIN Malang Press, 2008, Cet.I, h.8.

${ }^{10}$ Al-Rasyid \& Samsul Nizar, Filsafat Pendidikan Islam, Jakarta: Ciputat Press, 2005, h.30

${ }^{11}$ Ibid, h. 26

${ }^{12}$ Qs. Al-Isra' ayat 24
} 
Menurut Ki Hajar Dewantara pendidikan adalah usaha yang dilakukan dengan penuh keinsyafan yang ditujukkan untuk keselamatan dan kebahagiaan manusia. Pendidikan tidak hanya bersifat pelaku pembangunan tetapi sering merupakan perjuangan pula. Pendidikan berarti memelihara hidup tumbuh kearah kemajuan, tidak boleh melanjutkan keadaan kemarin menurut alam kemarin. Pendidikan adalah usaha kebudayaan, berasas peradaban, yakni memajukan hidup agar mempertinggi derajat manusia. ${ }^{13}$

Pengertian pendidikan dengan agak lebih terperinci lagi cakupannya dikemukakan oleh Soegarda Poerbakawaca. Menurutnya, dalam arti umum pendidikan mencakup segala usaha dan perbuatan dari generasi tua untuk mengalihkan pengalamannya, pengetahuannya, kecakapannya serta keterampilannya kepada generasi muda untuk melakukan fungsi hidupnya dalam pergaulan bersama sebaik-baiknya. ${ }^{14}$

Dengan demikian pendidikan berarti, segala usaha orang dewasa baik sadar dalam pergaulan dengan anak-anak untuk memimpin perkembangan jasmani dan rohaninya kearah kedewasaan menuju terciptanya kehidupan yang lebih baik. Sedangkan dalam konteks Islam, pendidikan dapat diartikan sebagai proses penyiapan generasi muda untuk mengisi peranan, memindahkan pengetahuan dan nilai-nilai Islam yang diselaraskan dengan fungsi manusia untuk beramal di dunia memetik hasilnya di akhirat. ${ }^{15}$

Adapun tujuan Pendidikan Islam, dikatakan oleh Zakiah Daradjat dalam buku Ilmu Pendidikan Islam, yaitu kepribadian seseorang yang membuatnya menjadi insan kamil dengan pola takwa, Insan Kamil artinya manusia utuh jasmani dan rohani, dapat hidup dan berkembang secara wajar dan normal karena takwanya kepada Allah SWT. Ini mengandung arti bahwa pendidikan Islam itu diharapkan menghasilkan manusia yang berguna bagi dirinya dan masyarkatnya serta senang dan gemar mengamalkan dan mengembangkan ajaran Islam dalam berhubungan dengan Allah dan dengan sesamanya, dapat mengambil manfaat yang semakin meningkat dari alam semesta ini untuk kepentingan hidup di dunia kini dan di akhirat nanti. ${ }^{16}$

Ketika seorang anak pertama kali ke dunia dan melihat apa yang ada di dalam rumah dan sekelilingnya, tergambar dalam benaknya sosok awal dari sebuah gambaran kehidupan. Bagaimana awalnya dia harus bisa melangkah dalam hidupnya di dunia ini. Jiwanya yang masih suci dan bersih akan menerima segala bentuk apa saja yang datang mempengaruhinya. Maka sang anak akan dibentuk oleh setiap pengaruh yang dating dalam dirinya. Pertumbuhan dan perkembangan seorang anak menurut para pakar ilmu jiwa ialah masa perubahan tubuh, intelegensi, emosional dan kemampuan interaksi yang memberi pengaruh pada utuhnya individu dan matangnya kepribadian.

Para ahli pendidikan dan pakar menetapkan bahwa setelah melewati masa kelahiran, seorang anak mengalami beberapa pertumbuhan dan perkembangan yang harus diketahui oleh orangtua untuk memudahkan dalam menentukan langkah pendidikan pada fase umur

\footnotetext{
${ }^{13}$ Abudin Nata, Filsafat Pendidikan Islam, (Jakarta: Logos Wacana Ilmu, 1997), Cet.1, h.9

${ }^{14}$ Ibid, h. 10

${ }^{15}$ Abudin Nata, Pendidikan Dalam Perspektif Hadits, (Jakarta: UIN Jakarta Press, 2005), Cet.I, h. 205.

${ }^{16}$ Nur Uhbiyati, Ilmu Pendidikan Islam,(Bandung: CV Pustaka Setia, 1999), Cet.2, h. 41.
} 
sehingga orangtua mampu membuat skedul program untuk diterapkan secara tepat dan sesuai dengan perkembangan dan pertumbuhan sehingga anak tumbuh besar bersama pendidikan secara alami. ${ }^{17}$

Imam al-Ghazali berkata: Anak adalah amanat bagi orangtuanya, hatinya bersih, suci dan polos. Kosong dari segala ukiran dan gambaran. Anak akan selalu menerima segala yang diukirnya, dan akan cenderung terhadap apa saja yang mempengaruhinya. Maka apabila dia dibiasakan dan diajarkan untuk melakukan kebaikan, niscaya akan seperti itulah anak terbentuk. Sehingga kedua orangtuanya akan mendapatkan kebahagiaan di dunia dan di akhirat. Sang anak akan menjadi orang yang terdidik. Namun apabila seorang anak dibiasakan untuk melakukan kejahatan dan ditelantarkan bagaikan binatang liar, sengsara dan celakalah ia. Dosanya akan ditanggung langsung oleh kedua orang tuanya sebagai penanggung jawab dari amanat Allah. ${ }^{18}$

Dalam kamus besar Bahasa Indonesia, Anak adalah keturunan dari ayah dan ibu atau keturununan yang kedua. ${ }^{19}$ Yang dimaksud anak dalam UU RI tentang perlindungan anak pasal I menyatakan anak adalah setiap manusia yang berusia di bawah 18 tahun, kecuali berdasarkan ketentuan yang berlaku bagi anak ditentukan bahwa usia dewasa dicapai lebih cepat. Dan termasuk anak yang masih dalam kandungan disebut juga anak. ${ }^{20}$ Anak adalah penerus cita-cita perjuangan bangsa. Selain sebagai amanah dari Allah SWT, anak juga merupakan cikal bakal yang akan memelihara, mempertahankan, dan mengembangkan hasil pembangunan demi kebahagiaan dunia akhirat. Oleh karena itu anak memerlukan perlindungan untuk menjamin pertumbuhan dan perkembangan fisik, mental, serta sosialnya secara utuh dan seimbang.

Memberikan perlindungan terhadap anak, baik jasmani maupun rahani, merupakan keharusan yang selaras dengan perintah Alah SWT. ${ }^{21}$ Dalam buku karangan Abdullah Nasih Ulwan, menurutnya anak adalah amanat Allah yang harus dibina, dipelihara, diurus secara seksama serta sempurna agar kelak menjadi insan kamil. ${ }^{22}$ Karena itu anak perlu mendapatkan pendidikan dari kedua orang tuanya, bahkan pendidikan anak, jika telah dilaksanakan dengan baik dan terarah, maka tidak lain adalah fondasi yang kuat untuk mempersiapkan pribadi yang shalih dan bertanggung jawab atas segala persoalan dan tugas hidupnya. Ulwan menambahkan lagi, materi yang diberikan berupa pendidikan moral, fisik, akal, jiwa, sosial, dan yang terpenting itu adalah agama. Bahkan menurut Ulwan pendidikan anak dapat dimulai ketika laki-laki (suami) memilih calonnya. Karena calon yang akan dipilih oleh laki-laki (istri) sangatlah mempengaruhi setiap kepribadian anak. Sebab anak akan lebih dekat hubungannya dengan ibu (calon yang dipilih), khususnya secara psikologis.

\footnotetext{
${ }^{17}$ Al Maghribi bin as-Said al-Maghribi, Begini Seharusnya Mendidik Anak, (Jakarta: Darul Haq), h. 131

${ }^{18}$ Abdul Hafizh, Mendidik Anak Bersama Rasulullah, (Bandung: al-Bayan, 1997), Cet. 1, h.35

${ }^{19}$ Ummi Chulsum, windy Novia, Kamus Besar Bahasa Indonesia, (Surabaya: Kashiko, 2006), Cet. I, h. 11-12

${ }^{20}$ Undang-undang RI, Tentang Perlindungan Anak No.23 Tahun 1997, (Surabaya: Media Center, 2006), Cet. 1, h. 119.

${ }^{21}$ Subhan Husain Albari, Agar Anak Rajin Solat, (Yogyakarta: DIVA Press, 2011), Cet. I, h. 11.

${ }^{22}$ Abdullah Nasih Ulwan, Pendidikan Anak dalam Islam, terjemahan dari tarbiyatul awlad fil islam oleh Jamaluddin Miri., (Jakarta: Pustaka Amani, 2002), Cet. 3, Jilid I, h. 7.
} 
Karena ketika istri mengandung dan menyusui secara tidak langsung telah meletakkan pondasi dasar atas prilaku dan karakter yang dimiliki oleh istri (ibu dari si anak). ${ }^{23}$

Cara mendidik anak adalah hendaknya mengajari akhlak-akhlak yang baik, kemudian menjaganya dari pergaulan yang buruk dan jangan membiasakannya berfoya-foya. Sebagaimana ungkapan Ibnu Qoyyim al-Jauziyah dalam kitabnya Tuhfatul Maudud fil Ahkamil Maulud yang dikutip oleh Muhammad Ali Qutb dalam bukunya yang berjudul Sang Anak dalam Lindungan Islam: Termasuk diantaranya hal yang sangat dibutuhkan didalam mendidik anak ialah memperhatikan masalah akhlak. Sang anak akan tumbuh sesuai dengan apa yang dibiasakan kepadanya oleh sang pendidik semasa sang anak masih kecil. Oleh karena itu kita jumpai banyak orang yang akhlaknya menyimpang dari kebenaran, yang disebabkan oleh pendidikan dimana ia dibesarkan. ${ }^{24}$

Dari ungkapan di atas jelaslah bahwa pendidikan orangtua terhadap anak mempengaruhi tingkah laku dan karakter anak tersebut. Termasuk dalam membina watak anak perlu memperhatikan bakat dan potensi yang terpendam di dalam diri anak yang sesuai dengan kecendrungannya. Ia harus dipersiapkan untuk melakukan hal-hal yang sesuai dengan pembawaannya, dan jangan sekali kali dibebankan kepadanya hal-hal yang tidak mampu dilakukannya mengingat bakatnya tidak sesuai dengan hal itu. Usaha orang tua dalam mendidik anak tidaklah semudah membalikkan telapak tangan. Orang tua harus memiliaki kesabaran dan kretivitas yang tinggi. Secara umum ada beberapa langkah yang perlu diperhatikan oleh para orang tua muslim dalam mendidik anak. Berikut beberapa langkah tersebut:

1. Memahami tentang konsep dan tujuan pendidikan anak

2. Banyak menggali informasi tentang pendidikan anak

3. Memahami kiat mendidik anak secara praktis. Dengan demikian setiap gejala dalam tahaptahap pertumbuhan anak dapat ditanggapi dengan cepat. ${ }^{25}$

Dalam undang-undang tentang sistem pendidikan nasional dinyatakan bahwa pendidikan anak usia dini adalah suatu upaya pembinaan yang ditujukan kepada anak sejak lahir sampai dengan usia enam tahun yang dilakukan melalui pemberian rangsangan pendidikan untuk membantu pertumbuhan dan perkembangan jasmani dan rohani agar anak memiliki kesiapan dalam memasuki pendidikan lebih lanjut. Dari penjelasan undang-undang tersebut, maka dapat kita pahami bahwa yang dimaksud dengan anak usia dini adalah anak pada masa pra sekolah, yaitu dimulai dari anak usia 0 tahun sampai 6 tahun. Sebagian pakar mengatakan bahwa yang dimaksud anak usia dini adalah dari 0 tahun sampai 8 tahun. Dan sebagaiamana dijelaskan dimuka bahwa dalam Islam untuk memulai pendidikan anak sejak masa pemilihan calon yaitu ibu.

Dengan demikian penulis menyimpulkan bahwasanya pendidikan anak usia dini adalah suatu proses transformasi pengetahuan, wawasan serta pengalaman hidup orang

\footnotetext{
${ }^{23}$ Imam Abu Hamid Muhammad bin Muhammad al-Ghazali, ihya 'ulumuddin, (Darul Fikri), jilid 3, h. 66.

${ }^{24}$ Muhammad Ali Qutb, Sang Anak dalam Lindungan Pendidikan Islam, (Bandung: CV Diponegoro, 1993), Cet, 2, h.9.

${ }^{25}$ Subhan Husain Albari, Agar Anak Rajin Solat...h.45.
} 
dewasa (di dalam hal ini lebih fokusnya adalah orangtua) kepada anak yang menjadi tanggung jawabnya dengan tujuan sang anak dapat menerima semua yang diajarkan secara sadar untuk direalisasikan dala kehidupan, seperti terbentuknya karakter yang kuat, bebas dan mandiri.

\section{Masa perkembangan anak}

Para pendidik atau orangtua harus mengenali perkembangan dan pertumbuhan anak secara alami sehingga mampu menentukan langkah dan kebijakan proses pendidikan secara benar maka hendaklah memperhatikan hal-hal dibawah ini:

1. Fase balita adalah masa menyusui dan menyapih yaitu setelah anak berumur 2 tahun. Beberapa ciri dibawah ini merupakan manifestasi dari adanya proses pekembangan pada bayi yaitu : Adanya perkembangan fisik nampak dari makin bertambahnya ukuran panjang dan berat badan bayi. Perkembangan motorik nampak dari adanya respon bayi terhadap rangsang berupa gerakan seluruh tubuh dan refleks-refleks. Perkembangan berpikir (kognitif) pada bayi di tandai oleh persyaratan rasa ingin tahu.

2. Fase balita antara umur 3 hingga 5 tahun yaitu masa pendidikan pra sekolah dan play group. Beberapa ciri perkembangan pada masa ini adalah:

a. Perkembangan motorik: dengan bertambah matangnya perkembangan otak yang mengatur sistem syaraf otot (neuromuskuler) memungkinkan anak-anak usia ini lebih lincah dan aktip berrgerak.

b. Perkembangan bahasa dan berfikir: Kemampuan berbicara lisan pada anak akan berkambang karena terjadi selain oleh pematangan dari organ - organ bicara dan berpikir,juga karena lingkunga ikut membantu mengembangkannya

3. Fase kanak-kanak yaitu antara umur 6 hingga 8 tahun yaitu fase anak mulai masuk sekolah dasar. Tahap usia ini disebut juga sebagai usia kelompok (gangage), di mana anak mulai mengalihkan perhatian dan hubungan intim dalam keluarga ke kerjasama antar teman dan sikap-sikap terhadap kerja atau belajar. Dengan memasuki S.D. salah satu hal penting yang perlu dimiliki anak adalah kematangan sekolah. Pada masa anak sekolah ini ,anak -anak membandingkan dirinya dengan teman-temannya dimana ia mudah sekali dihinggapi ketakutan akan kegagalan dan ejekan teman, bila pada masa ini ia sering gagal dan merasa cemas akan tumbuh rasa rendah diri, sebaliknya bila ia tahu tentang bagaimana dan apa yang perlu dikerjakan dalam menghadapi tuntutan masyarakatnya dan ia berhasil mengatasi masalah dalam hubungan teman dan prestasi sekolahnya ,akan timbul motivasi yang tinggi terhadap karya dengan lain perkataan terpupuklah "industry"

4. Fase peralihan yaitu umur 9 hingga 12 tahun yaitu akhir anak memperoleh pendidikan dasar. Dimulai dengan tumbuhnya gigi baru sampai timbulnya gejala berfungsinya kelenjar-kelenjar kelamin (seksual). 
5. Fase remaja atau baligh yaitu umur 12 hinga 15 tahun yaitu umur pertumbuhan anggota tubuh dan kematangan secara psikologi atau kewajiban bagi anak laki-laki dan anak perempuan.

6. Fase puberitas usia 15 hingga 18 tahun yaitu fase anak sudah duduk di bangku SMU.

7. Masa produktif umur 18 hingga 30 tahun.

8. Masa dewasa yaitu masa peralihan dari produktif hingga umur enam puluh tahun.Masa manula yaitu masa mulai umur enam puluh. ${ }^{26}$ Disini penulis mengambil fase balita hingga fase kanak-kanak, yaitu antara anak umur 0 tahun hingga anak masuk sekolah dasar.

\section{Langkah-langkah mendidik anak}

Proses pembentukan tingkah laku atau kepribadian hendaklah dimulai dari masa kanak-kanak, yaitu sejak selesainya masa menyusui hingga anak berumur enam tahun. Masa ini termasuk masa yang sangat sensitive bagi perkembangan kemampuan berbahasa, cara berpikir, dan sosialisasi anak. Di dalamnya, terjadi proses pembentukan jiwa anak yang menjadi dasar keselamatan mental dan moralnya.

Pentingnya pendidikan Islam oleh para orang tua terhadap anak-anak mereka didasarkan oleh sabda Rasulullah SAW yang menegaskan bahwa setiap anak dilahirkan dalam keadaan fitrah. Kedua orangtuanyalah yang menjadikan anak-anak itu Nasrani, Yahudi atau Majusi. Hal tersebut juga didukung oleh teori psikologi perkembangan yang menegaskan bahwa masing-masing anak dilahirkan dalam keadaan seperti kertas putih. Teori ini dikenal dengan "Tabularasa", yang menyatakan bahwa setiap anak dilahirkan dalam keadaan bersih, ia akan menerima pengaruh dari luar lewat indera yang dimiliki.

Tentang pentingnya peranan orangtua dalam pendidikan anak di lingkungan keluarga ini, Allah swt berfirman:

Hai orang-orang yang beriman, peliharalah dirimu dan keluargamu dari api neraka yang bahan bakarnya adalah manusia dan batu; penjaganya malaikat-malaikat yang kasar, keras, dan tidak mendurhakai Allah terhadap apa yang diperintahkan-Nya kepada mereka dan selalu mengerjakan apa yang diperintahkan. (Q.S. At-Tahrim/22: 6)

Ada beberapa aspek pendidikan yang perlu diterapkan oleh para orangtua dalam hal membentuk tingkah laku atau kepribadian anak mereka sesuai dengan tuntunan al-Qur'an dan hadist. Diantara aspek-aspek tersebut adalah pendidikan yang berhubungan dengan penanaman atau pembentukan dasar keimanan (akidah), pelaksanaan ibadah, akhlak, dan lain sebagainya. Memang usaha orangtua dalam mendidik anak tidaklah semudah membalikan telapak tangan. Orangtua harus memiliki kesabaran dan kreativitas yang tinggi. Secara umum ada beberapa langkah yang perlu diperhatikan oleh para orangtua muslim dalam mendidik anak. Berikut beberapa langkah tersebut:

1. Memahami tentang konsep dan tujuan pendidikan anak.

2. Banyak menggali informasi tentang pendidikan anak.

${ }^{26}$ Al-Maghribi bin as-Said al-Maghribi, Begini Seharusnya Mendidik Anak...h.132. 
3. Memahami kiat mendidik anak secara praktis. Dengan demikian, setiap gejala dalam tahap-tahap pertumbuhan anak dapat ditanggapi dengan cepat.

Cara mudah mendidik anak dengan nilai-nilai yang baik antara lain orangtua harus terlebih dahulu mempraktikannya sebelum nilai tersebut ditransfer kepada anak. Orangtua harus menjamin lingkungan anak sesuai dengan ajaran Islam. Selain itu orangtua harus menjalankan fungsinya masing-masing. ${ }^{27}$

\section{Metode Penanaman Nilai-nilai Islam pada Diri Anak}

Pendidikan atau penanaman nilai-nilai Islam pada diri anak akan berhasilNbila diwujudkan dengan mengikuti langkah-langkah yang baik dan benar. Sehubungan dengan hal ini, Abdurrahman an-Nahwali mengemukakan tujuh kiat dalam mendidik anak. Berikut adalah ketujuh kiat tersebut:

1. Hiwar (Dialog)

Mendidik anak dengan cara dialog merupakan suatu keharusan bagi orangtua. Oleh karena itu kemampuan berdialog mutlak harus ada pada setiap orangtua. Dengan dialog, akan terjadi komunikasi yang dinamis antara orangtua dengan anak, serta lebih mudah dipahami dan berkesan. Selain itu orangtua akan mengetahui perkembangan pemikiran dan sikap anak. Rasulullah saw juga menerapkan langkah ini dalam mendidik anak.

2. Kisah

Mendidik anak dengan cara berkisah sangat penting bagi perkembangan jiwa anak. Sebuah kisah yang baik akan menyentuh jiwa dan memotivasi anak untuk mengubah sikap. Kalau kisah yang diceritakan itu baik, maka sifat baik tokoh tersebut akan ditiru oleh anak yang bersangkutan. Banyak sekali kisah-kisah sejarah, baik kisah para nabi, sahabat, pahlawan, atau orang-orang shalih, yang bisa dijadikan sebagai pelajaran dalam membentuk keprinbadian anak. Fenomena semakin banyaknya anak yang pemalas, tidak mau berusaha dan tidak menerima beres merupakan salah satu dampak dari kisah khayalan yang menampilkan pribadi-pribadi pemalas, tetapi selalu ditolong dan diberi kemudahan.

Cerita tentang kisah-kisah yang mengandung hikmah sangat efektif untuk menarik perhatian anak dan merangsang otaknya agar bekerja dengan baik, bahkan metode ini dianggap yang terbaik dari cara-cara lain dalam mempengaruhi pola piker anak. Karena dengan mendengar cerita, anak merasa senang sekaligus menyerap nilai-nilai pendidikan tanpa merasa dijejali. Cara seperti ini telah dicontohkan oleh Rasulullah saw sejak dulu, beliau seringkal bercerita tentang kisah kaum-kaum terdahulu agar dapat diambil hikmah dan pelajarannya.

Ada satu hal penting yang haru digarisbawahi, yaitu bahwa kisah kisah yang diceritakan Rasulullah saw bukanlah cerita bohong belaka, melainkan riwayat-riwayat yang jelas latarbelakangnya dan sejarahnya serta yang paling mengandung nilai-nilai pendidikan dan ruh keislaman yang dapat mendorong anak yang mendengarkan untuk

${ }^{27}$ Subhan Husain Albari, Agar Anak Rajin Solat...h.45-46. 
bersikap sesuai dengan akhlak luhur dan mulia yang diajarkan oleh Islam kepada seluruh umatnya. ${ }^{28}$

3. Perumpamaan

Al-Qur'an dan hadits banyak sekali mengemukaan perumpamaan. Jika Allah swt dan Rasul-Nya mengungkapkan perumpamaan, secara tersirat berarti orang tua juga harus mendidik anak-anaknya dengan perumpamaan orang harus terus menerus memberikan arahan terhadap anaknya sampai sang anak betul-betul menyadari bahwa kalau mau disayang oleh orangtua, yang dilakukan sang anak adalah rajin shalat, giat belajar dan hormat kepada kedua orangtuanya. Begitu juga dengan persoalan-persoalan lainnya.

4. Keteladanan

Orangtua merupakan pribadi yang sering ditiru oleh anak-anaknya. Kalau perilaku orangtua baik, maka anak akan meniru hal-hal yang baik. Sebaliknya, bila perilaku orangtua buruk, maka anaknya akan meniru hal-hal yang buruk pula. Dengan demikian, keteladan yang baik merupakan salah satu kiat orangtua menginginkan anak-anaknya menjadi anak yang shalih, maka yang harus menjadi shalih terlebih dahulu adalah orangtua.

Metode ini merupakan metode yang paling unggul dan paling jitu dibandingkan metode-metode lainnya. Melalui metode ini para orangtua, pendidik memberi contoh atau teladan terhadap anak/peserta didiknya bagaimana cara berbicara, berbuat, bersikap, mengerjakan sesuatu atau cara beribadah dan sebagainya.

Melalui metode ini maka anak/peserta didik dapat melihat, menyaksikan dan meyakini cara yang sebenarnya sehingga mereka dapat melaksanakannya dengan lebih baik dan lebih mudah. Maksudnya adalah dalam hal kebaikan dan kebenaran, apabila kita menghendaki orang lain juga mengerjakannya, maka mulailah dari diri kita sendiri untuk mengerjakannya.

5. Latihan dan Pengamalan

Anak yang shalih bukan hanya rajin berdoa untuk kedua orangtuanya, tetapi, ia juga berusaha secara maksimal untuk melaksanakan ajaran Islam dalam kehidupan sehari-hari. Agar dapat mengajarkan amalan Islam, seorang anak harus dilatih sejak dini. Ia harus dilatih sejak awal tentang shalat, puasa, berjibab, dan lain sebagainya. Tanpa latihan yang dibiasakan, seorang anak akan sulit mengamalkan ajaran Islam, meskipun ia telah memahaminya. Oleh karena itu, seorang ibu harus menanamkan kebiasaan yang baik kepada anak-anaknya dan melakukan control agar seorang anak disiplin dalam melaksanakan ajaran Islam

6. Ibrah dan Mau'izah

Para orangtua bisa mengambil pelajaran bagi anak-anaknya dari berbagai kisah, misalnya tentang sejarah. Begitu pula dengan peristiwa yang actual, bahkan dari kehidupan makhluk lain, banyak sekali pelajaran yang bisa diambil. Bila orangtua sudah berhasil mengambil pelajaran dari suatu kejadian bagi anak anaknya, langkah berikutnya

\footnotetext{
${ }^{28}$ Abdul Hafizh, Mendidik Anak Bersama Rasulullah...h. 301.
} 
adalah memberikan nasihat (mau'izah) yang baik. Memberi nasihat itu tidak selalu harus dengan kata-kata. Nasihat bisa dilakukan melalui kejadian-kejadian tertentu yang menggugah hati seperti menjenguk orang sakit, takziah, ziarah ke kubur dan lain sebagainya.

7. Targhib dan Tarhib

Targhib adalah janji-janji yang menyenangkan bagi seseorang yang melakukan kebaikan, sedangkan tarhib adalah ancaman yang mengerikan terhadap orang yang melakukan keburukan. Banyak sekali ayat dan hadist yang mengungkapkan janji dan ancaman. Itu artinya, orangtua juga mesti menerapkan metode dalam mendidik anaknya. ${ }^{29}$

Pahala dari mendidik anak sangatlah besar, malah apabila orangtua berhasil dalam mendidik sehingga anak-anaknya menjadi shalih maka pahalanya mengalir terus meskipun orangtuanya telah meninggal. Hal ini dijelaskan dalam

hadist: "Apabila anak Adam (manusia) sudah mati, maka putuslah semua amalnya, kecuali tiga hal : shadaqah jariyahnya, ilmunya yang bermanfaat, dan anaknya yang shalih yang mendoakannya" (HR. Muslim)

Berbahagialah para orangtua yang berhasil dalam mendidik anak-anaknya sehingga menjadi shalih. Namun untuk mewujudkan itu bukanlah suatu hal yang mudah, karena banyak halangan dan rintangan, terlebih lagi pada masa kini manakala teknologi dan informasi sudah sangat maju yang apabila tidak hati-hati akan mendatangkan kemudaratan (ketidakbaikan) serta pergaulan anak muda sudah banyak yang menyimpang dan cenderung kepada ke maksiatan.

Di sinilah tugas orang tua menjadi semakin berat, untuk itu perlu kesabaran dan ketaatan dalam beragama supaya pendidikan terhadap anak bisa berjalan lancar. ${ }^{30}$ Metode ini merupakan metode yang mendorong anak didik untuk belajar suatu bahan pelajaran atas dasar minat yang berkesadaran pribadi terlepas dari paksaan atau tekanan mental. Belajar berdasrkan motif-motif yang bersumber dari kesadaran pribadi dipandang oleh ahli psikologi sebagai suatu kegiatan positif yang membawa keberhasilan proses belajar. $^{31}$

\section{Materi Pendidikan Anak Usia Dini}

Istilah materi pendidikan berarti mengorganisir bidang ilmu pengetahuan yang membentuk basis aktivitas lembaga pendidikan, bidang-bidang ilmu pengetahuan ini satu dengan yang lainnya dipisah-pisah namun merupakan satu kesatuan utuh terpadu. Materi pendidikan harus mengacu kepada tujuan, bukan sebaliknya tujuan mengarah kepada suatu

\footnotetext{
${ }^{29}$ Ibid.

${ }^{30}$ Hamdani Ihsan, Fuad Hasan, Filsafat Pendidikan Islam, (Bandung: Pustaka Setia, 2007), Cet. III, h. 180.

${ }^{31}$ Abdurrahman Saleh Abdullah, Teori-Teori Pendidikan Berdasarkan Al-Qur'an, (Jakarta: Rineka Cipta, 2005), h. 159.
} 
materi, oleh karenanya materi pendidikan tidak boleh berdiri sendiri terlepas dari kontrok tujuannya.

Materi atau isi pelajaran yang disusun sebelumnya harus ditentukan dahulu tujuan yang hendak dicapai dengan mempertimbangkan skil-skil atau keterampilanketerampilan, para pelajar itu akan gagal manakala pemikiran kritis dan imajinatif hanya mampu mencapai taraf rendah. Oleh karena itu sulit kiranya untuk menerima pandangan, bahwa materi atau isi pendidikan itu akan mencapai tujuan maksimal hanya dengan mempertimbangkan materi pelajaran yang lain. $^{32}$

Orang tua wajib mengajarkan syariat sebagai pendorong bagi anak-anak untuk berperangai luhur dan mulia, di samping mengajarkan kepandaian dan keterampilan untuk membuka pintu nafkah hidup mereka di masa depannya.Untuk mengarungi lautan kehidupan keduniawian dan keakhiratan, anak perlu mendapatkan tiga kelompok materi, yaitu :

1. Tarbiyah Jismiyah

Dengan materi tarbiyah jismiyah, anak akan mendapatkan sarana dan prasarana pendidikan dari orangtuanya berupa fasilitas untuk menyehatkan, menumbuhkan, dan menyegarkan tubuhnya. Mereka berhak tumbuh dengan tegar, sehingga mampu mamdiri dalam menghadapi tantangan kehidupan dan kesulitan fisik yang dialami demi kesempurnaan hidupnya. Untuk kebutuhan fisik anak, orangtua harus selektif dalam memberikan pemenuhannya agar ada keseimbangan kebutuhan duniawi dan akhiratnya. Pemberian makanan harus dengan pertimbangan dapat meninggikan akhlaknya, yaitu menjaga mereka dari sifat berlebihan. Demikian pula dengan pakaian, harus menunjukan akhlakul karimah sesuai dengan syariat, menghindari hidup bermewah-mewahan, dan budaya anti keselamatan dunia dan akhirat.

Orangtua berkewajiban membantu perkembangan fisik anak, sekaligus memenuhinya dengan doa dan nilai-nilai keagamaan, sehingga mendapatkan barakah dari Allah swt sepenuhnya. Selain itu perlu ditanamkan rasa malu agar anak tidak tumbuh dan berkembang menjadi anak liar, tidak pandai bersukur, tamak dan sombong. Hindarkan mereka dari segala sesuatu yang merugikan kepentingan dunia akhiratnya melalui teladan yang baik dari seluruh anggota keluarganya yang ada disekelilingnya. ${ }^{33}$

2. Tarbiyah Aqliyah

Dalam materi tarbiyah aqliyah, anak diberi kesempatan memperoleh pendidikan dan pengajaran yang mencerdaskan dan menanjamkan akal. Perlu diingat bahwa orangtua mempunyai peluang yang cukup besar untuk mengembangkan akhlak mulia, melalui pendidikan berhitung, fisika, kimia dan materi lainnya. Dengan menerapkan metode "integrated curricular", para orangtua dapat membantu proses tumbuh-kembangkan kecerdasan anak, sekaligus meninggikan akhlaknya. Tanamkan keihklasan dalam menuntut ilmu dan kesabaran dalam mengikuti proses transfer ilmu pengetahuan. Tanamkan pada anak sifat hormat kepada para pendidiknya, menghargai prestasi

\footnotetext{
32 Juwariyah, Dasar-Dasar Pendidikan Anak dalam Al-Qur'an, (Yogyakarta: Teras, 2010), h. 103.

33 Maimunah Hasan, PAUD (Pendidikan Anak Usia Dini), (Yogyakarta, Diva Press, 2009), h. 30-31.
} 
kawannya. Tumbuhkan sikap kompetitif sehat dalam meraih prestasinya, sehingga tidak tumbuh sikap iri dan dengki terhadap sesamanya. Semua upaya tersebut akan membantu anak-anak tumbuh cerdas dalam ruang lingkup rasa sukur. Dalam kehidupan sehariharinya, akhlak mulia sang anak akan tercermin dalam perilakunya yang penuh tanggung jawab, baik dalam belajar, penyampaian, maupun penerapannya. ${ }^{34}$

3. Tarbiyah Ruhaniyah atau Tarbiyah Adabiyah

Dalam materi tarbiyah ruhaniyah atau tarbiyah adabiyah, unsur-unsur perataan yang telah berbarengan dengan pendidikan jasmani dan akal mereka, akan disempurnakan melalui nasehat yang baik. Sehingga, diharapkan mampu menghaluskan dan menyempurnakan keluhuran budi anak. ${ }^{35}$ Dalam konteks itulah maka perlu kiranya pendidikan versi Luqman yang memberikan dasarnya dengan keimanan kepada tuhan digali dan diangkat kembali ke permukaan untuk dijadikan tauladan bagi pelaksanaan proses pendidikan anak yang hidup di alam global di mana mayoritas para orangtua tidak lagi memiliki banyak peluang untuk memberikan kebutuhan dasar anak-anak mereka. Menjadikan keimanan kepada ke-Esaan Allah swt sebagai landasan dasar bagi pendidikan anak-anak merupakan sesuatu yang wajib dilakukan oleh orangtua dan orang-orang dewasa sebagai pendidik dan pembimbing mereka, karena hal itu akan memberikan dampak positif serta implikasi yang sangat luas terhadap perkembangan jiwanya. ${ }^{36}$ Anak akan menjadi apa kelak, tergantung bagaimana kedua orangtua membimbingnya. Oleh karena itu dalam the golden years ini, hendaknya diperhatikan enam segi fondasi dalam mendidik anak:

a. Segi Ketuhanan dan Spiritual

1) Menanmkan prinsip agama dan mengokohkan fondasi Iman.

2) Menanamkan ketataan terhadap agama.

3) Mencarikan teman yang baik.

4) Memperhatikan kegiatan anak.

b. Segi Moral

1) Kejujuran dan tidak munafik

2) Menjaga lisan dan berakhlak mulia

c. Segi Mental dan Intelektual

1) Menyenangi bacaan yang bermutu yang dapat meningkatkan kualitas diri

2) Menjaga diri dari hal-hal yang merusak akal

d. Segi jasmani

1) Diberi nafkah wajib dan kebutuhan dasar anak, seperti makanan dan tempat tinggal, kesehatan, pakaian dan pendidikan

2) Latihan jasmani, berolahraga, menunggang kuda, berenang, memanah.

3) Menghindari dari kebiasaan yang merusak jasmani

e. Segi Psikologis

${ }^{34}$ Ibid
${ }^{35}$ Ibid
${ }^{36}$ Ibid 
Gejala malu, takut, minder, manja, egois dan pemarah

\section{f. Segi Sosial}

1) Menunaikan hak orang lain dan setiap yang berhak dalam kehidupan

2) Etika sosial anak. ${ }^{37}$

\section{Simpulan}

pendidikan berasal dari kata "didik" yang diberi awalan "pe" dan akhiran "kan", mengandung arti "perbuatan" (hal, cara dan sebagainya). Isitilah pendidikan ini semula berasal dari bahasa yunani yaitu "Paedagogie", yang berarti bimbingan yang diberikan kepada anak.

Masa perkembangan anak yaitu:

1. Fase balita.

2. Fase balita antara umur 3 hingga 5 tahun

3. Fase kanak-kanak

4. Fase peralihan yaitu umur 9 hingga 12

5. Fase remaja atau baligh yaitu umur 12 hinga 15 tahun

6. Fase puberitas usia 15 hingga 18 tahun

7. Masa produktif umur 18 hingga 30 tahun.

8. Masa dewasa

Beberapa langkah yang perlu diperhatikan oleh para orangtua muslim dalam mendidik anak. Berikut beberapa langkah tersebut:

1. Memahami tentang konsep dan tujuan pendidikan anak.

2. Banyak menggali informasi tentang pendidikan anak.

3. Memahami kiat mendidik anak secara praktis. Dengan demikian, setiap gejala dalam tahap-tahap pertumbuhan anak dapat ditanggapi dengan cepat.

Abdurrahman an-Nahwali mengemukakan tujuh kiat dalam mendidik anak. Berikut adalah ketujuh kiat tersebut: Hiwar (Dialog), Kisah, perumpamaan, keteladanan, latihan, ibrah, Targhib dan Tarhib.

${ }^{37}$ Maimunah Hasan, PAUD (Pendidikan Anak Usia Dini), (Yogyakarta, Diva Press, 2009), h. 30-31 


\section{DAFTAR PUSTAKA}

Ahmad, Nurwadjah, Tafsir Ayat-Ayat Pendidikan: Hati yang Selamat Hingga Kisah Luqman, Bandung: Marja, 2007

Ahmadi, Lif Khoiro, Hendro, Sofan, Pembelajaran Akselerasi, Jakarta: PT Prestasi Pustaka, 1998

Albari, Subhan Husain, Agar Anak Rajin Solat, Yogyakarta: DIVA Press, 2011

Ali Qutb, Muhammad, Sang Anak dalam Lindungan Pendidikan Islam, Bandung: CV Diponegoro, 1993

Al-Khalidy, Shalah, Kisah-Kisah Al-Qur'an: Pelajaran Dari Orang-Orang Dahulu, Jakarta: Gema Insani Press, 2000

Al-Maroghi, Ahmad Musthofa, Tafsir Al-Maroghi, Kairo: Musthofa Al-Bab Al Halab, 1946

Al-Rasyid, Samsul Nizar, Filsafat Pendidikan Islam, Jakarta: Ciputat Press, 2005

Arikunto, Suharsimi, Prosedur penelitian Suatu Pendekatan Praktek, Jakarta: Rineka Cipta,1990

Baidan, Nashruddin, Metodologi Penafsiran Al-Qur'an, Pustaka Pelajar,1998

Bin as-Said al-Maghribi, Al-Maghribi, Begini Seharusnya Mendidik Anak, Jakarta: Darul Haq

Bin Muhammad al-Ghazali, Imam Abu Hamid Muhammad, ihya 'ulumuddin Jilid 3, Darul Fikri

Bin Muhammad Al-Hanafi, Ishomuddin Ismail, Hasyiah Al-Qunawi ala Tafsiri Al-Imam AlBaidhawi Juz 15, Beirut, Dar Al-Kutub Al-Ilmiyah, 2001

Chulsum, Ummi, windy Novia, Kamus Besar Bahasa Indonesia, Surabaya: Kashiko, 2006

Daradjat, Zakiah, Ilmu Pendidikan Islam, Jakarta: Bumi Aksara, 1996

Departemen Agama, Al-Qura'an dan Tafsirnya Jilid VII, Semarang: Departemen Agama Republik Indonesia, 1990

Departemen Agama, Al-Quran dan Terjemahannya, Jakarta: Departemen Agama, 2002

Hafizh, Abdul, Mendidik Anak Bersama Rasulullah, Bandung: al-Bayan, 1997

Hasan, Maimunah, PAUD (Pendidikan Anak Usia Dini), Yogyakarta, Diva Press, 2009

Ihsan, Hamdani, Fuad Hasan, Filsafat Pendidikan Islam, Bandung: Pustaka Setia, 2007

Jalaludin, Psikologi Agama, Jakarta: PT Raja Grafindo,1998

Juwariyah, Dasar-Dasar Pendidikan Anak dalam Al-Qur'an, Yogyakarta: Teras, 2010

Muchtar, Jauhari, Fikih Pendidikan, Bandung: Remaja Rosdakarya, 2005

Mursid, Kurikulum dan Pendidikan Anak Usia Dini (PAUD) Sebuah Harapan Masyarakat, Semarang:Aktif Media,2009 
Mushtoffa, Aziz, Aku Anak Hebat Bukan Anak Nakal, Yogyakarta: Diva Press, 2009

Nasih Ulwan, Abdullah, Pendidikan Anak dalam Islam, terjemahan dari tarbiyatul awlad fil islam oleh Drs. Jamaluddin Miri.Lc, Jakarta: Pustaka Amani, 2002

Nata, Abudin, Filsafat Pendidikan Islam, Jakarta: Logos Wacana Ilmu, 1997

Nata, Abudin, Pendidikan Dalam Perspektif Hadits, Jakarta: UIN Jakarta Press, 2005

Nazir, Moh, Metode Penelitian, Jakarta : Ghalia Indonesia, 1999

Ramayulis, Ilmu Pendidikan Islam, Jakarta: Kalam Mulia, 2002

Rosyidi, Anwar, dkk, Terjemahan Tafsir Al-Maraghi, Semarang: Karya Toha Putra, 1992

Saleh Abdullah, Abdurrahman, Teori-Teori Pendidikan Berdasarkan Al-Qur'an, Jakarta: Rineka Cipta, 2005

Shihab, M.Quraish, Tafsir Al-Misbah Pesan Kesan dan Keserasian Al-Qur'an Vol 15, Jakarta: Lentera Hati, 2002

Siregar, Masarudin, Filsafat Pendidikan Islam, Semarang: Fakultas Tarbiyah, 2003

Sugiyono, Metode Penelitian Pendidikan Kuantitatif, Kualitatif dan R\&D, Bandung: alfabeta, 2008

Syah, Muhibin, Psikologi Belajar, Jakarta: PT. Raja Grafindo Persada, 2003

Tafsir, Ahmad, Ilmu Pendidikan Islam, Bandung: Remaja Rosda Karya, 2007

Tim Penyusun Kamus Pusat Pembinaan dan Pengembangan Bahasa Departemen

Pendidikan dan Kebudayaan, Kamus Besar Bahasa Indonesia, Jakarta: Balai Pustaka, 1994

Uhbiyati, Nur, Ilmu Pendidikan Islam, Bandung: CV Pustaka Setia, 1999

Undang-Undang RI No. 2 Tahun 1989 Tentang Sistem Pendidikan Nasional dan Penjelasannya, Semarang: Aneka Ilmu, 1992

Undang-undang RI, Tentang Perlindungan Anak No.23 Tahun 1997, Surabaya: Media Center, 2006

Yasin, A.Fattah, Dimensi-dimensi Pendidikan Islam, Malang: UIN Malang Press, 2008

Zuhairini dkk, Filsafat Pendidikan Islam, Jakarta: Bumi Aksara, 2004 